\title{
O gênero narrativo \\ e Renato Russo: a formação de leitores cidadãos
}

REVISTA ELETRÔNICA

CIENTIIFICA DA UERGS

Lilian da Silva Carvalho.

Escola Municipal de Ensino Fundamental Alberto Pasqualini (E.M.F.A.P.) /Escola Estadual de Educação Básica Gomes Carneiro (E.E.E.G.C.)

E-mail: liliandasilva87@hotmail.com, http://lattes.cnpq.br/0796783272690734

Ana Carolina Martins da Silva

Universidade Estadual do Rio Grande do Sul (Uergs).

E-mail: ana-martins@uergs.edu.br, http://lattes.cnpq.br/7364759247330I83

Submetido em: I 8 ago. 202 I. Aceito: I I nov. 202 I DOI: http://dx.doi.org/I0.21674/2448-0479.73.248-257

\section{Resumo}

Adaptação de Trabalho de Conclusão de Curso apresentado à Especialização em Teoria e Prática da Formação do Leitor, na Universidade Estadual do Rio Grande do Sul, em Porto Alegre, em 2017. A questão de pesquisa: "Como as músicas com traços de gênero narrativo podem unir poesia, arte e educação emancipadora para formação de leitores críticos?" o inspirou, e foi usada a metodologia de pesquisa bibliográfica, usando fontes como: websites, encartes de cds, livros, monografias, teses, bem como de comunicações orais: gravações em vídeo (via Youtube); e filmes. Com a hipótese de que este tipo de canção de teor narrativo pode fomentar reflexões profundas dentre os ouvintes, a partir de sua identificação com os dramas dos personagens, o objeto escolhido foi "Faroeste Caboclo", do autor e compositor Renato Russo. O objetivo geral foi verificar se essa música poderia responder à questão de pesquisa. Como resultado, observou-se que sua Letra demonstra os dramas e angústias que vive o ser humano num contexto adverso; trata-se de uma história cantada, permeada pelos elementos da narrativa; permitindo ao leitor a apropriação dos valores simbólicos discutidos na canção, além de poder vir a servir como recurso didático na formação de leitores emancipados e críticos, a partir de mediações pedagógicas adequadas para tal.

Palavras-chave: Educação; formação de leitores; renato russo; faroeste caboclo; gênero narrativo.

\section{Abstract}

\section{The narrative genre and Renato Russo: the formation of readers}

Adaptation of Course Conclusion Paper presented to the Specialization in Theory and Practice of Reader Education, at the Universidade Estadual do Rio Grande do Sul, in Porto Alegre, in 2017. The research question: "How can songs with narrative genre traits unite poetry, art and emancipatory education to train critical readers?" inspired him, and the bibliographic research methodology was used, using sources such as: websites, CD inserts, books, monographs, theses, as well as oral communications: video recordings (via Youtube); and movies. With the hypothesis that this type of song with a narrative content can foster deep reflections among listeners, based on its identification with the characters' dramas, the chosen object was "Faroeste Caboclo", by author and composer Renato Russo. The general objective was to verify if this song could answer the research question. As a result, it was observed that its lyrics demonstrates the dramas and anxieties that human beings experience in an adverse context; it is a sung story, permeated by the elements of the narrative; allowing the reader to appropriate the symbolic values discussed in the song, in addition to being able to serve as a didactic resource in the formation of emancipated and critical readers, based on pedagogical mediations suitable for this purpose.

Keywords: Education; reader training; renato russo; faroeste caboclo; narrative genre. 


\section{Resumen \\ El género narrativo y Renato Russo: la formación de lectores ciudadanos}

Adaptación del Trabajo de Conclusión de Curso presentado en Especialização em Teoria e Prática da Formação do Leitor, de la Universidade Estadual do Rio Grande do Sul, en Porto Alegre, en 20I7. La pregunta de investigación: "¿Cómo pueden las canciones con trazos de género narrativo unir la poesía, el arte y la educación emancipadora para formar lectores críticos?» inspiró este trabajo, y se utilizó la metodología de investigación bibliográfica, utilizando fuentes como: sitios web, encartes de CD, libros, monografías, tesis, así como comunicaciones orales: grabaciones de video (vía Youtube) y películas. Con la hipótesis de que este tipo de canción de contenido narrativo puede generar profundas reflexiones entre los oyentes, a partir de su identificación con los dramas de los personajes, el objeto elegido fue "Faroeste Caboclo", del autor y compositor Renato Russo. El objetivo general fue verificar si esta canción podría responder a la pregunta de investigación. Como resultado, se observó que su letra demuestra los dramas y angustias que vive el ser humano en un contexto adverso; es una historia cantada, impregnada de elementos de la narración, permitiendo al lector apropiarse de los valores simbólicos discutidos en la canción, además de poder servir como recurso didáctico en la formación de lectores emancipados y críticos, a partir de mediaciones pedagógicas adecuadas para tal fin.

Palabras clave: Educación; formación de lectores; renato russo; faroeste caboclo; género narrativo.

\section{Introdução}

Trabalho realizado a partir da problematização: "Como as músicas com traços de gênero narrativo podem unir poesia, arte e educação emancipadora para formação de leitores críticos?". O tema foi: "O gênero narrativo em músicas de Renato Russo como estratégia de formação de leitores emancipados." A hipótese formulada denota que este tipo de canção pode fomentar reflexões profundas dentre os ouvintes, a partir de sua identificação em termos de contexto e drama, com os personagens apresentados. Divide-se em: I: Introdução - apresentação; 2: Educação, libertação e a anatomia dos leitores-cidadãos: a educação libertadora; aspectos do conceito de leitor, caracterização, e sua transformação pela leitura. 3: O gênero narrativo e a poesia narrativa de Renato Russo: Faroeste Caboclo e elementos da narrativa; análise da Letra, sob visões do gênero narrativo e da tragédia; 4: Leitores/ouvintes de Renato Russo - atitudes criativas e responsivas à obra. Seu resultado não encerra o resgate da inserção do artista e cidadão Renato Russo no cenário artístico e cultural do Brasil, mas pode contribuir como revisão bibliográfica e reflexão na área da Teoria e Prática da formação do Leitor, a partir de textos que contam grandes experiências de vida.

\section{Educação, libertação e a anatomia dos leitores-cidadãos}

A escola, no "passado", era um espaço social, porém, voltado mais à adaptação dos sujeitos ao mundo, do que à sua libertação; suas pedagogias primavam mais pela informação, do que pela formação. A leitura, em grande parte, dentro deste processo, tornava-se mera decodificação e repetição, sendo incapaz de proporcionar aos estudantes uma ampla interação com o texto, além de torná-lo um objeto de estudo concreto, analisado, descontruído e fragmentado. Atualmente, essa realidade é um pouco diferente, graças a estudiosos inquietos que comprovaram que ler não é apenas dissecar representações gráficas.

Seja na alfabetização, aquela que promove independência na vida do educando e o contato do educando e o seu contato com o conhecimento adquirido através da escrita e da leitura, ou seja, no Letramento; seja nos anos mais adiantados da Escola, o uso libertador e emancipador da leitura e da escrita são fundamentais. De acordo com Lois (2010, p. 18), a escrita/código permite o acesso ao mundo dos adultos e a assimilação dos valores da sociedade. Para a autora, a reflexão do educador, ao ensinar a ler, deve refletir sobre as práticas pedagógicas, evitando apenas a reprodução de conhecimentos. "Isto quer dizer, que o professor não estará proporcionando a independência crítica e renovadora ao educando, mas possibilitando ao mesmo, que se torne um analfabeto funcional, por este motivo é preciso ter cuidado ao adotar algumas práticas pedagógicas." (LOIS, 2010, p.18). 
Tomando a expressão "que se torne", percebe-se que a autora deixa indissociáveis a cultura escrita e a evolução humana. Segundo o Dicionário Priberam!: "anatomia" vem do latim anatomia, ae, do grego anatome - es, dissecção, e seu significado gira em torno de: "arte de dissecar as partes dos corpos organizados para lhes estudar a estrutura". O corpo é composto de instrumentos orgânicos que necessitam de estímulos e, quando a palavra "anatomia" está associada a "leitores-cidadãos", percebe-se que um desses estímulos pode ser o ato de ler, ou seja, a interação entre autor, texto e leitor, no momento da leitura; ou em prática de mediação de leitura: uma personagem de um livro indicando outro livro para leitura; um ambiente organizado na sala de aula. Ler é mais do que um ato mecânico, é um movimento cultural que atravessa a pessoa, partes físicas e psicológicas em interação. Em resposta a uma imagem, cujo nome é $A$ Anatomia do Leitor, na qual constam as diferentes possibilidades de acesso à leitura a partir do corpo humano, e que, postada pelo blog "Overmundo" obteve 2 I 4 downloads (na data revistada: I5/08/202I), Fonseca (2013) diz:

A formação do leitor inicia-se no seu esqueleto humano, utilizando-se dos seus órgãos essenciais para a possibilidade de diversificar o seu próprio conhecimento de mundo, através do livro e compreendendo a essência do seu lugar no mundo. (FONSECA, 2013, In OVERMUNDO).

A imagem de um menino desenhado ${ }^{2}$, cercado por palavras e setas direcionadas respectivamente: aos olhos: "olhos, para ver pistas nas imagens e palavras"; à testa: "mente curiosa, para pensar nas ideias dos livros"; à boca: "boca, para ler com a expressividade de um contador"; à orelha: "ouvidos, para escutar o que os outros pensam"; à mão: "mãos, para cuidar dos livros com carinho; ao peito: "coração, para se unir às histórias; ao livro em suas mãos: "livros, livros, livros muitos e muitos livros!", como se o livro fosse um dos pedaços do corpo, buscada no Google ${ }^{3}$, aparece em muitas ocorrências, só na primeira página, em 17; é replicada em redes, e em blogs, tais como: Aprender a Brincar'; Viajando pelo Mundo da Leitura ${ }^{5}$; Projeto do Professor ${ }^{6}$; Bom livro, bom amigo ${ }^{7}$, dentre outros; é alvo de inúmeras releituras fotográficas e em desenho, fortalecendo a popularização de que ler é mais do que decodificar, é viver, sentir, respirar, bater de coração, ouvir, e outras manifestações orgânicas e viscerais, o que auxilia a evolução individual e coletiva.

Segundo Lois (2010, p. 72): "O texto não existe sem o leitor. Os livros só existem porque há um leitor que ilumina pelo seu olhar. A palavra escrita, da bula ao mais denso texto literário, necessita comunicar-se com alguém.". Pode-se afirmar, portanto, que a relação entre o texto e o leitor é muito importante para ambos, pois na medida em que um necessita do outro para existir, o contato torna-se significativo e relevante. Entretanto, é preciso atenção para que não morra a essência da obra, pois o leitor é influenciado por elementos internos e externos, podendo obter uma ótica diferente da obra produzida pelo artista. A relação entre autor e leitor mediada pelo ato da escrita e da leitura estabelece uma comunicação entre diferentes percepções de vida, que, talvez, nunca se colocassem frente a frente, se não fosse nesse tipo de mediação. A comunicação entre esses elementos só é possível por intermédio do texto/mensagem como um elo. Caso a mensagem passe por muitas interferências, no final, não será a mesma para ambos. Este intervir pode ser social, cultural ou, até mesmo, o meio de divulgação, e, por isso, há a importância da teoria e da análise textual, o que se efetua a seguir.

\section{O gênero narrativo e a poesia narrativa de Renato Russo}

Para Marcuschi, gênero é algo que está entre o discurso e o texto. $O$ autor vê o gênero "como prática social e prática textual-discursiva". Explica que: "Ele opera como uma ponte entre o discurso como uma atividade mais universal e $o$ texto enquanto a peça empírica particularizada e configurada numa determinada

I “anatomia”, in Dicionário Priberam da Língua Portuguesa [em linha], 2008-202 I, https://dicionario.priberam.org/anatomia [consultado em 15-08-202I].

2 Knight, Andrea. A Anatomia do leitor. from: https://www.teacherspayteachers.com/Store/Andrea-Knight

3 Google (1998) é um website privado, considerado o mais visitado do mundo, que hospeda e desenvolve serviços e produtos na internet, além de tornar informação algo compartilhado mundialmente.

4 Disponível em: https://www.aprenderebrincar.com/2016/03/anatomia-de-um-leitor.html

5 Disponível em: https://viajandoonomundodaleitura.wordpress.com/2018/10/22/anatomia-de-um-leitor/

6 Disponível em: http://projetoprofessor.blogspot.com/2016/05/a-anatomia-de-um-leitor-anatomia-de-um.html

7 Disponível em: https://ebipv.wordpress.com/2013/09/24/anatomia-de-um-leitor/ 
composição observável." (MARCUSCHI, 2008, p. 84). Essa determinada "composição observável" advém de uma escolha. Marcuschi (2008, p. 85) aponta:

O gênero é uma escolha que leva consigo uma série de consequências formais e funcionais. Na realidade, se observamos como agimos nas nossas decisões na vida diária, dá-se o seguinte: primeiramente, tenho uma atividade a ser desenvolvida e para a qual cabe um discurso característico. Esse discurso inicia com a escolha de um gênero que por sua vez condiciona uma esquematização textual. (MARCUSCHI, 2008, p. 85).

Considerando gênero e texto como escolhas que emergem de relações contextuais, estabelecidas entre esses objetos e sua situacionalidade ou inserção cultural, social, histórica e cognitiva (MARCUSCHI, 2008, p. 87), é possível perceber que Renato Russo era influenciado pelo seu meio e recebia influências de suas leituras. O seu estilo musical e sua preferência, também recebiam influências, principalmente por Bob Dylan, que seria o ápice de sua referência de identidade e, também, de expressão escrita. Seu conhecimento era vasto, assim como sua capacidade e criatividade. Sabia expressar seus sentimentos e reflexões, além de registrar sua revolta com a política. Através de sua obra, sua poesia cantada expressava denúncia, como no caso das canções: "Que Pais É Este", "Geração Coca-Cola”; em outras, filosofava, como na Letra da música "Monte Castelo" e até narrava histórias, como a do casal romântico "Eduardo e Mônica"; e na história do jovem "João de Santo Cristo", da música "Faroeste Caboclo" imerso em uma tragédia.

Vieira (200I), que revisitou teorias da "elaboração do conceito de estrutura narrativa a partir dos anos sessenta e de sua crítica, em estudos publicados nos anos oitenta", faz uma síntese, concluindo a primeira parte de seu texto, em dois princípios: "Podemos formular que para haver uma narrativa é preciso que haja I) uma relação cronológica e lógica entre os eventos e as ações dos atores; e, 2) que os eventos tenham uma organização macro-proposicional." (VIEIRA, 200I, p. 604).

Emediato (2004, p. 149), quando aborda o modo de organização do discurso narrativo, vê um "esquema narrativo". "A matéria é o fato, constituído por agentes que materializam as suas ações em definidas circunstâncias. Os elementos fundamentais da narrativa são, pois, os personagens, os fatos, as ações que os constituem e as circunstâncias." (EMEDIATO, 2004, p. 150). Para o autor: "A narração é, em suma, um relato organizado de acontecimentos, reais ou fictícios, no interior do qual se desenvolve uma intriga, ou seja, um enredo.". O autor cita perguntas a serem respondidas pela narrativa: “- O quê? O fato, a ação (enredo); - Quem? Personagens envolvidos; - Onde? O lugar da ocorrência dos fatos; - Como? O modo como se desenvolveram os acontecimentos; - Por quê? A causa, razão, motivo dos acontecimentos; - Qual o resultado ou consequência? (EMEDIATO, 2004, p. I50).

O autor ainda faz o resgate de alguns elementos estruturais que, segundo ele, "parecem fundadores do gênero narrativo" e os quais são encontrados em Faroeste Caboclo: "- criação de uma expectativa para a personagem; - surgimento de um obstáculo ou conflito; - busca da resolução do conflito; - resolução do conflito (sucesso ou fracasso); avaliação (moral, didática)" (EMEDIATO, 2004, p. 150 - 15I). Elementos esses que estão bem consubstanciados em Vieira (200I), quando retoma Vladimir Propp (1928/I983) e os seus "alicerces da narratologia", que consideram "as suas partes constitutivas e as relações destas partes entre si e com o conjunto.". (VIEIRA, 200I, p 599), passando por Adam (1984), que, por sua vez, retoma a sociolinguística de Labov e Waletzky (1967). Vieira (200I, p. 602) diz que: "a narrativa vai ter uma superestrutura textual composta de macro-proposições de orientação, complicação, ação ou avaliação, resolução, conclusão ou moral”. Outras teorias estudam a estrutura narrativa, mas esse trabalho vai ficar com essa base: a) considerar a Letra da música como texto narrativo; b) considerar que esse texto, junto com seu autor, sofre influências internas e externas; c) considerar que a sua superestrutura textual está clara e é tão forte que pode transformar-se em um discurso influenciador de seus leitores/ouvintes no ciclo: autor, mensagem, leitor.

Russo era a voz da juventude dos anos 80; foi imortalizado pela sua capacidade intelectual e pôde conceder, em suas Letras, voz às histórias de muitos jovens da época. Por este motivo, neste trabalho acadêmico, a Letra escolhida é "Faroeste Caboclo", do álbum "Que País É Esse", de 1987, devido às suas características narrativas predominantes: o elemento trágico de João de Santo Cristo, que desenvolve, ao longo da música, o seu lado anti-herói. Essa música, por conter tantas informações e formações, pôde ser adaptada pelo diretor René Sampaio para o cinema, outra arte que Renato adorava.

A Letra conta a história de João de Santo Cristo, toda sua trajetória, até chegar na sua morte espetacular em Brasília. A canção foi escrita em 1979, por Renato Russo, e sacramentada em LP em 1987, com a banda 
Legião Urbana. A apresentação desta música não agradou ao público punk ${ }^{8}$, conforme explícito no encarte do CD - LEGIÃO URBANA, I987:

Com duração de nove minutos, apresentada pela primeira vez (sob vaias dos punks) no Morro da Urca, em 1983. A música é de 1979, anterior a "Eduardo e Mônica", seguindo a mesma linha: uma estória completa com personagens, começo, meio e fim. A Letra (como todas as outras do disco) permanece no original, rimas pobres e tudo. (LEGIÃO URBANA, 1987).

Entretanto, o LP da banda Legião Urbana conseguiu bater recordes de vendas, e a música rejeitada pelo público Punk, seria a canção mais tocada nas rádios, apesar de conter uma longa duração de tempo. Conforme Dapieve (2000, p. 93):

Que país é este chegou ao topo da parada de LPs mais vendidos, com mais de 240 mil cópias [...] Tão incrível quanto a vendagem do disco era o fato de Faroeste Caboclo ter se tornado - a despeito dos 9 minutos de duração... - a música mais pedida na programação da maior parte das FMs cariocas [...] No Brasil de 1988, qualquer criança de sete anos cantava os 157 versos de cor e salteado. (DAPIEVE, 2000, p. 93):

Após esse pequeno fato histórico da canção, inicia-se a análise, a partir dos elementos da narrativa, identificados conceitualmente e aplicados na Letra da canção.

\section{Os elementos da narrativa são:}

Narrador (quem conta a história).

Em Faroeste, o narrador está em terceira pessoa, ele apresenta diretamente os personagens, o que se confirma a seguir; "Dizia ele: "Estou indo pra Brasília/ Neste país lugar melhor não há / Tô precisando visitar a minha filha / Eu fico aqui você vai no meu lugar" (RUSSO, EMI, 1998), este é o momento marcado pelo discurso em que se estabelece o encontro entre Santo Cristo e o boiadeiro, que the para ir em pede seu lugar para Brasília. O narrador é uma das chaves principais, pois é um narrador onisciente (sabe de tudo) e, por esse motivo, durante a narrativa, assume um papel de espécie de testemunha dos fatos e conta a história. À medida em que o narrador conta a história, o ouvinte pode construir as cenas quase que cinematograficamente. Não é à toa que a canção foi adaptada para o cinema, o que lhe proporcionou mais notoriedade e gerou premiação por Melhor Longa', em 20 I4. Ao todo, foram sete prêmios Grande Otelo, incluindo os de filme, ator (Fabrício Boliviera) e roteiro adaptado.

O enredo ${ }^{10}$ ( $\mathrm{O}$ quê? $\mathrm{O}$ fato, a ação); o esquema narrativo.

\section{a. Criação de uma expectativa para a personagem:}

Não tinha medo o tal João de Santo Cristo / Era o que todos diziam quando ele se perdeu / Deixou pra trás todo o marasmo da fazenda / Só pra sentir no seu sangue o ódio que Jesus lhe deu / Quando criança só pensava em ser bandido / Ainda mais quando com um tiro de soldado o pai morreu / Era o terror da sertania onde morava / E na escola até o professor com ele aprendeu / la pra igreja só pra roubar o dinheiro / Que as velhinhas colocavam na caixinha do altar / Sentia mesmo que era mesmo diferente / Sentia que aquilo ali não era o seu lugar / Ele queria sair para ver o mar / $E$ as coisas que ele via na televisão / Juntou dinheiro para poder viajar / De escolha própria, escolheu a solidão / Comia todas menininhas da cidade / De tanto brincar de médico, aos doze era professor / Aos quinze, foi mandado pro reformatório / Onde aumentou seu ódio diante

8 punk |pânque| (palavra inglesa) substantivo masculino

I. Movimento de contestação e provocação cultural e social, sobretudo através da música, do vestuário, dos penteados e dos comportamentos, nascido nos anos 70 do século XX, na Grã-Bretanha. “punk”, in Dicionário Priberam da Língua Portuguesa [em linha], 2008-2021, https://dicionario.priberam.org/punk [consultado em 16-08-202I].

9 Disponível em: https://www.correiobraziliense.com.br/app/noticia/diversao-e-arte/20 /4/08/26/interna_diversao_arte,444279/ grande-premio-do-cinema-brasileiro-consagra-faroeste-caboclo.shtml acesso em 17.08.202I.

10 RUSSO, R. Faroeste Caboclo. Disponível em: https://www.Letras.mus.br/legiao-urbana/22492/ (8.257.850 exibições no acesso em $16 / 08 / 2021)$. 
de tanto terror / Não tinha medo o tal João de Santo Cristo / Era o que todos diziam quando ele se perdeu / Deixou pra trás todo o marasmo da fazenda / Só pra sentir no seu sangue o ódio que Jesus lhe deu / Quando criança só pensava em ser bandido / Ainda mais quando com um tiro de soldado o pai morreu / Era o terror da sertania onde morava / E na escola até o professor com ele aprendeu / la pra igreja só pra roubar o dinheiro / Que as velhinhas colocavam na caixinha do altar / Sentia mesmo que era mesmo diferente / Sentia que aquilo ali não era o seu lugar / Ele queria sair para ver o mar / E as coisas que ele via na televisão / Juntou dinheiro para poder viajar / De escolha própria, escolheu a solidão / Comia todas menininhas da cidade / De tanto brincar de médico, aos doze era professor / Aos quinze, foi mandado pro reformatório / Onde aumentou seu ódio diante de tanto terror (RUSSO, EMI, 1998).

\section{b. Surgimento de um obstáculo ou conflito:}

Não entendia como a vida funcionava / Discriminação por causa da sua classe e sua cor / Ficou cansado de tentar achar resposta / E comprou uma passagem, foi direto a Salvador / E lá chegando foi tomar um cafezinho / E encontrou um boiadeiro com quem foi falar / E o boiadeiro tinha uma passagem e ia perder a viagem / Mas João foi lhe salvar/ Dizia ele: Estou indo pra Brasília / Neste país lugar melhor não há / Tô precisando visitar a minha filha / Eu fico aqui e você vai no meu lugar / E João aceitou sua proposta / E num ônibus entrou no Planalto Central / Ele ficou bestificado com a cidade / Saindo da rodoviária, viu as luzes de Natal / Meu Deus, mas que cidade linda / No Ano Novo eu começo a trabalhar / Cortar madeira, aprendiz de carpinteiro / Ganhava cem mil por mês em Taguatinga / Na sexta-feira ia pra zona da cidade / Gastar todo o seu dinheiro de rapaz trabalhador / $\mathrm{E}$ conhecia muita gente interessante / Até um neto bastardo do seu bisavô / Um peruano que vivia na Bolívia / E muitas coisas trazia de lá / Seu nome era Pablo e ele dizia / Que um negócio ele ia começar / E Santo Cristo até a morte trabalhava / Mas o dinheiro não dava pra ele se alimentar / E ouvia às sete horas o noticiário / Que sempre dizia que o seu ministro ia ajudar / Mas ele não queria mais conversa / $\mathrm{E}$ decidiu que, como Pablo, ele iria se virar / Elaborou mais uma vez seu plano santo / E sem ser crucificado, a plantação foi começar / Logo, logo os maluco da cidade souberam da novidade / Tem bagulho bom aí! / E João de Santo Cristo ficou rico / E acabou com todos os traficantes dali / Fez amigos, frequentava a Asa Norte / E ia pra festa de rock pra se libertar / Mas de repente / Sob uma má influência dos boyzinhos da cidade / Começou a roubar / Já no primeiro roubo ele dançou / E pro inferno ele foi pela primeira vez / Violência e estupro do seu corpo / Vocês vão ver, eu vou pegar vocês! (RUSSO, EMI, 1998).

c. Busca da resolução do conflito:

Agora o Santo Cristo era bandido / Destemido e temido no Distrito Federal / Não tinha nenhum medo de polícia / Capitão ou traficante, playboy ou general / Foi quando conheceu uma menina / E de todos os seus pecados ele se arrependeu / Maria Lúcia era uma menina linda / E o coração dele, pra ela o Santo Cristo prometeu / Ele dizia que queria se casar / E carpinteiro ele voltou a ser / Maria Lúcia, pra sempre vou te amar / E um filho com você eu quero ter / O tempo passa e um dia vem na porta / Um senhor de alta classe com dinheiro na mão / $E$ ele faz uma proposta indecorosa / $E$ diz que espera uma resposta, uma resposta do João / Não boto bomba em banca de jornal / Nem em colégio de criança, isso eu não faço, não / $E$ não protejo general de dez estrelas / Que fica atrás da mesa com o cu na mão / E é melhor o senhor sair da minha casa / Nunca brinque com um Peixes de ascendente Escorpião / Mas antes de sair, com ódio no olhar, o velho disse / Você perdeu sua vida, meu irmão / Você perdeu a sua vida, meu irmão / Você perdeu a sua vida, meu irmão / Essas palavras vão entrar no coração / Eu vou sofrer as consequências como um cão (RUSSO, EMI, 1998).

\section{d. A resolução do conflito (sucesso ou fracasso):}

Não é que o Santo Cristo estava certo / Seu futuro era incerto e ele não foi trabalhar / Se embebedou e no meio da bebedeira / Descobriu que tinha outro trabalhando em seu lugar / Falou com Pablo que queria um parceiro / E também tinha dinheiro e queria se armar / Pablo trazia o contrabando da Bolívia / E Santo Cristo revendia em Planaltina / Mas acontece que um tal de Jeremias / Traficante de renome, apareceu por lá / Ficou sabendo dos planos de Santo Cristo / E decidiu que com João ele ia acabar / Mas Pablo 
trouxe uma Winchester-22 / E Santo Cristo já sabia atirar / E decidiu usar a arma só depois / Que Jeremias começasse a brigar / Jeremias, maconheiro sem-vergonha / Organizou a Rockonha e fez todo mundo dançar / Desvirginava mocinhas inocentes / Se dizia que era crente, mas não sabia rezar / E Santo Cristo há muito não ia pra casa / E a saudade começou a apertar / Eu vou-me embora, eu vou ver Maria Lúcia / Já tá em tempo de a gente se casar Chegando em casa então ele chorou / E pro inferno ele foi pela segunda vez / Com Maria Lúcia, Jeremias se casou / E um filho nela ele fez / Santo Cristo era só ódio por dentro / E então o Jeremias pra um duelo ele chamou / Amanhã às duas horas na Ceilândia / Em frente ao lote 14, e é pra lá que eu vou / $E$ você pode escolher as suas arma/ Que eu acabo mesmo com você, seu porco traidor / E mato também Maria Lúcia / Aquela menina falsa pra quem jurei o meu amor / E o Santo Cristo não sabia o que fazer / Quando viu o repórter da televisão / Que deu notícia do duelo na TV / Dizendo a hora e o local e a razão / No sábado então, às duas horas / Todo o povo sem demora foi lá só para assistir / Um homem que atirava pelas costas / E acertou o Santo Cristo começou a sorrir / Sentindo o sangue na garganta / João olhou pras bandeirinhas e pro povo a aplaudir / E olhou pro sorveteiro e pras câmeras / E a gente da TV que filmava tudo ali / $E$ se lembrou de quando era uma criança / $E$ de tudo o que vivera até ali / E decidiu entrar de vez naquela dança / Se a Via-Crucis virou circo, estou aqui / E nisso o Sol cegou seus olhos / E então Maria Lúcia ele reconheceu / Ela trazia a Winchester-22 / A arma que seu primo Pablo Ihe deu / Jeremias, eu sou homem, coisa que você não é / E não atiro pelas costas, não / Olha pra cá filha da puta, sem-vergonha / Dá uma olhada no meu sangue e vem sentir o teu perdão (RUSSO, EMI, 1998).

\section{e. Avaliação (moral, didática):}

E Santo Cristo, com a Winchester-22 / Deu cinco tiros no bandido traidor / Maria Lúcia se arrependeu depois / E morreu junto com João, seu protetor / E o povo declarava que João de Santo Cristo / Era santo porque sabia morrer / E a alta burguesia da cidade / Não acreditou na história que eles viram na TV / E João não conseguiu o que queria / Quando veio pra Brasília com o diabo ter / Ele queria era falar pro presidente / Pra ajudar toda essa gente que só faz / Sofrer. (RUSSO, EMI, 1998).

\section{f. O tempo da narrativa:}

É desenvolvido cronologicamente, vai acompanhando o amadurecimento do Santo, em direção ao futuro; porém, o coro, no início da narrativa, retoma a lembrança do lendário Santo Cristo, do passado:"Não tinha medo o tal João de Santo Cristo/ Era o que todos diziam quando ele se perdeu...". Na segunda estrofe, o narrador volta no tempo, descrevendo toda a trajetória de vida de Santo da infância até a fase da maior idade: "Meu Deus...mas que cidade linda/ No ano novo, eu começo a trabalhar". Outro exemplo, é quando Santo está "morrendo": "E se lembrou de quando era uma criança/ E de tudo o que vivera até ali/ E decidiu entrar de vez naquela dança..." (RUSSO, EMI, 1998). Por fim, a retrospectiva de vida de todas as lembranças vem à tona, desde a infância à fase adulta.

\section{g. Espaço da narrativa:}

A escolha do espaço é fundamental para narrativa, unindo a cultura do personagem com a local para desenvolver a história. Soares (2007, p. 5 I) define: "Também denominado ambiente, cenário ou localização, o espaço é o conjunto de elementos da paisagem exterior (espaço físico) ou interior (espaço psicológico), onde se situam as ações dos personagens.". Para a autora: "É ele imprescindível, pois não funciona apenas como pano de fundo, mas influencia diretamente no desenvolvimento do enredo, unindo-se ao tempo". (SOARES, 2007, p. 5I).

Considerando o espaço, pode-se analisar que, na canção "Faroeste Caboclo", cada um teve seu peso, o da infância, por ser provinciano; e Brasília, por ser metrópole demais. Destaca-se também o título da música, que faz alusão aos filmes de faroeste norte-americanos, nos quais o cowboy era considerado um destemido, bandido que vivia entre tiros, mortes e amores, unindo à realidade brasileira com o adjetivo "caboclo". Então, a vida de Santo é de um brasileiro, pois se envolve com a criminalidade ao longo da narrativa. É preciso salientar que João sentia-se um estranho em seu lugar na infância, pois era o "terror" de sua cidade: "E sentia que aquele não era o seu lugar”, isto é, não era o seu ambiente, não sentia perspectivas naquele lugar. O pro- 
tagonista sentindo-se deslocado, mudou de cidade, encantado com a nova, o que se comprova com o seguinte trecho: "Ele ficou bestificado com a cidade. Meu Deus mas que cidade linda. (RUSSO, EMI, 1998).

Renato Russo não era da criminalidade, mas conseguiu representar em seu poema esse tipo de "EU" com propriedade, tanto que a canção se tornou um sucesso nas periferias. É possível que seu conhecimento sobre Brasília, Ihe tenha dado a verdade sobre as relações do cidadão que vem do interior e que acaba sendo consumido por ela, transformando sua vida em uma grande tragédia.

Com a história de amor de Santo Cristo por uma mulher "proibida", e que, a seu modo, assume grandes riscos, sendo punido no final da história com a morte, Russo imita um roteiro de tragédia. Faroeste Caboclo possui "o coro", cuja função é proporcionar a reflexão dos problemas evidenciados. Identifica-se o coro na voz do povo, que leva o ouvinte para o tempo mítico na narrativa e para uma reflexão do destino de Santo: "Não tinha medo o tal João de Santo Cristo/ Era o que todos diziam quando ele se perdeu / Deixou pra trás todo o marasmo da fazenda / Só pra sentir no seu sangue o ódio que Jesus lhe deu" (RUSSO, EMI, 1998). Durante a narrativa, quando ocorre o duelo entre Jeremias e Santo, mais uma vez o coro emite seu julgamento: "E o povo declarava que João de Santo cristo/ Era santo porque sabia morrer". Neste trecho, o narrador separa a voz do povo e o coro é identificando por dois tipos de comunidade: "E a alta burguesia da cidade / não acreditou na história que eles viram na tv". A seguir, João representa a comunidade popular, pois ele não era pertencente à alta burguesia, e morreu como herói, pois durante sua trajetória conseguiu aguentar o peso de seu fardo: pobreza e destino miseráveis. Esse heroísmo é reconhecido pelo "coro" tendo em vista que ele não quis atirar pelas costas em Jeremias: "soube morrer". Todos os julgamentos do coro são apresentados pelo narrador: "E o povo declarava que...". A tragédia também é evidenciada através do pequeno trecho da música a seguir: "E Santo Cristo com a Winchester 22 / Deu cinco tiros no bandido traidor / Maria Lúcia se arrependeu depois / E morreu junto com João, seu protetor” (RUSSO, EMI, 1998).

Desta forma, tem-se um poema repleto de elementos da narrativa que, ao mesmo tempo, coloca como pano de fundo instrumentos musicais acompanhando o seu desenvolvimento. Na canção, podemos perceber que há muitas mudanças no ritmo, nos momentos cruciais que ocorrem na vida do protagonista. Este ritmo consegue levar o leitor/ouvinte a imaginar e sentir, ao mesmo tempo, as emoções que o personagem sentia, pois os acordes musicais são intercalados entre melódicos e compassados. Do início da narrativa até a $14^{\mathrm{a}}$ estrofe, o ritmo é melódico, passando ao leitor tranquilidade durante a narrativa. $\mathrm{Na} I 5^{\mathrm{a}}$ estrofe, começa a ficar mais acelerado o ritmo, é quando o protagonista chega ao Planalto Central, o que mudará sua vida; envolve-se com drogas e criminalidades; quando conhece Maria Lúcia, a canção volta a ser mais tranquila e melódica, pois a jovem muda sua vida. No encontro com um senhor de alta classe, na $23^{\mathrm{a}}$ estrofe, a melodia começa a acelerar aos poucos, mas vai ser evidenciada nas estrofes $26^{\mathrm{a}}$ a $37^{\mathrm{a}}$, momento em que o ritmo acelera com fortes batidas de bateria e som de guitarra. $\mathrm{Na}$ estrofe $38^{\mathrm{a}}$, ela volta a ser mais tranquila, quando ocorre a morte de João Santo Cristo, de Jeremias e de Maria Lúcia.

Durante o desenrolar da vida de Santo Cristo, percebe-se que seu destino estava em suas mãos, pois suas decisões são cruciais para o desfecho de seu destino e da narrativa, o que pode provocar reflexões nos jovens, já que a música mostra a ascensão e a queda de um rapaz que se envolve com o submundo do crime (tráfico de drogas, assalto e assassinato) e esta é a realidade de muitas comunidades de renda baixa, que não vê que esse submundo não leva a lugar algum, a não ser à morte, como aconteceu com a vida trágica de João de Santo Cristo.

\section{Leitores/ouvintes de Renato Russo: atitudes emancipatórias e responsivas}

Nesta seção, apresenta-se a análise dos depoimentos de três "leitores/ouvintes", que foram sensibilizados pela história de Santo Cristo e tiveram atitudes "responsivas" a elas: Trabalho acadêmico (A), Filme (B) e Crônica (C). Foram utilizados três questionamentos, cujas respostas emergiram dos textos, ou seja, as perguntas foram respondidas com base nos escritos dos indivíduos ( $A, B$ e $C$ ) citados acima, publicados em meios de comunicação. São: a) "A música como possibilidade de desenvolvimento humano", de 2010, por uma professora do Programa de Desenvolvimento Educacional (PDE) / Universidade do Paraná: Neusa Maria Vasques Bulla; b) entrevista do diretor do filme "Faroeste Caboclo" para o site "Adoro Cinema": René Sampaio; c) depoimento do cronista que, durante sua trajetória de jornalista, escreveu crônicas e livros sobre Renato: Arthur Dapieve.

Sondando-se o trabalho acadêmico de Neusa Maria Vasques Bulla (20I0): A Letra da música "Faroes- 
te Caboclo" pode despertar nos ouvintes sentimento de empatia ou de crítica? pode-se constatar que a autora conseguiu desenvolver atividades e análises com os alunos da rede pública do Paraná, tendo como ponto de partida as músicas de Renato Russo. Além disto, ela realizou uma crítica com a audição da músi$\mathrm{ca}$, estabelecendo relação entre dificuldade de convívio em grupo que Santo tinha, com o destino de seu pai, assassinado, e com a morte, associando suas "dificuldades para se adaptar às instituições sociais, tais como: a igreja, a escola e o reformatório.". O fato de não ter referências de família, ou formação, é significativo para ele. Disse: "O que resta para ele é a imagem do pai morto por um tiro de soldado.". (BULLA, 20I0, p. 26). O diretor do filme "Faroeste Caboclo", por sua vez, conta que ao ouvir a música, passou a ter interesse em produzir um filme, pois conseguiu visualizar cinematograficamente a narrativa, "ao ouvir a música, aos I4 anos." (SAMPAIO, ([ 20I-?])."'; Em sua crônica "Chuvas e trovoadas"'2, Dapieve (20I5) comenta ter ficado em dúvida se estava diante de um livro, ou um disco: " fiquei em dúvida se o melhor lugar para a resenha seria a "Discolândia" mesmo ou o "Prosa \& verso". [...] Depois de repetidas audições me mostraram que ele era um disco mesmo. E dos bons." (DAPIEVE, 20I5, p. 210). Nota-se, portanto, que todos tiveram alguma reação impactante diante das obras.

Para a pergunta: A poesia "Faroeste Caboclo", por possuir estrutura narrativa, pode ser transformada em outro gênero textual? Qual? Observou-se, em Bulla (2010), que o primeiro leitor transformou a narrativa em desenho; o segundo, fez a adaptação para roteiro de cinema, conforme explicita Sampaio ([ $201-?])^{13}$ : "Tivemos de transformar uma experiência de nove minutos em uma de cem minutos."; $O$ terceiro produziu crônicas, comprovando recriação criativa, não apenas da periferia, mas de pessoas de diferentes origens e formações.

Por fim, para a pergunta: a poesia que traz características de discussão e de crítica social, como "Faroeste Caboclo" pode ser utilizada como suporte para estratégias de leitura que formem leitores críticos? Para Bulla (2010), sim, pois conseguiu fomentar atividades de leitura e de interpretação; produção de outros textos verbais e não verbais. Sampaio (s/d) produziu um filme premiado: "Quando interpretamos uma obra, temos de nos esforçar para que esta segunda obra seja completa.". Na explicação, retoma a palavra "escolha": "Ao fazer as escolhas necessárias, respeitamos o drama. Uma música respeita a métrica, a rima, o ritmo.” (SAMPAIO, ([20 I?]). ${ }^{14}$

\section{Considerações finais}

Essa experiência foi de extrema riqueza, pois foi possível observar elementos, tanto de vidas individuais, quanto de história coletiva, sob a ótica da formação do leitor. A essência da canção (RUSSO, EMI, 1998) utilizou vários elementos contidos em grandes obras consideradas "livros clássicos", de forma "enxuta", na Letra de Faroeste Caboclo: longa, narrativa, dramática, trágica e emancipadora. Sua melodia faz o leitor/ouvinte sentir no peito cada ato relatado, reforçando o quanto é importante trabalhar Música e Letra na escola, quebrando monotonias e permitindo trocas de acervos. Fica evidenciado que Renato Russo, passados mais de 20 anos de sua morte, ainda exerce influências, e pode ajudar na educação de jovens, aliando-se, à escola na defesa da vida.

\section{Agradecimentos:}

Às docentes da Banca: Profa. Dra. Veronice Camargo da Silva e Profa. Esp. Lurdes Denise Crispim Moreira que, com suas observações cooperativas e amorosas, qualificaram esse trabalho.

I I Disponível em: http://globofilmes.globo.com/noticia/faroeste-caboclo-9/

12 Publicação original em O GLOBO, "Segundo Caderno”, I9/9/1996.

13 Disponível em: http://globofilmes.globo.com/noticia/faroeste-caboclo-9/

14 Disponível em: http://globofilmes.globo.com/noticia/faroeste-caboclo-9/ 


\section{Referências}

BULLA, N.M.V. A música como possibilidade de desenvolvimento humano: crítico, leitura, oralidade e escrita. In Cadernos PDE, Volume II: O professor PDE e os desafios da Escola Pública Paranaense, PARANÁ, 20I0. Disponível em: http://www.diaadiaeducacao.pr.gov.br/portals/cadernospde/pdebusca/producoes_pde/2010/2010_uem_ped_pdp_ neusa_maria_vasques_bulla.pdf. Acesso em 16 de jan. 2019.

DAPIEVE, A. BRock: O rock brasileiro dos anos 80. São Paulo, Editora 34, 2015.

DAPIEVE, A. Renato Russo - O Trovador Solitário. Rio de Janeiro: Editora Relume Dumará, 2000.

EMEDIATO, W. A fórmula do texto: redação e argumentação e leitura. São Paulo: Geração Editorial, 2004.

FONSECA, S.G. da. Anatomia de um leitor!!!. In Overmundo, comentário postado em 17/1/2013. Disponível em: http://www.overmundo.com.br/banco/anatomia-de-um-leitor. Acesso em 04 de jan. 2019.

GLOBO FILMES. Faroeste caboclo - o filme. Disponível em: http://globofilmes.globo.com/noticia/faroeste-caboclo-9/ . Acesso em 10 de jan.2019.

INFO ESCOLA. Tragédia Grega. Disponível em: http://www.infoescola.com/artes/tragedia/ . Acesso em: 8 de fev. 2019.

LEGIÃO URBANA. Que país é este - 1978/1987. EMI, 1998. Encarte. I CD digital estéreo remasterizado.

LOIS, L. Teoria e prática da formação do leitor: leitura e literatura na sala de aula. Porto Alegre: Artmed, 2010.

MARCUSCHI, L. A. Produção Textual, análise de gêneros e compreensão. São Paulo: Parábola, 2008.

RENATO RUSSO. Biografia de Renato Russo. Disponível em: http://www.renatorusso.com.br/bio/ . Acesso: 02 de fev.2019.

RODRIGUES, L.de O. Estilo punk: Brasil Escola. Disponível em http://brasilescola.uol.com.br/sociologia/estilo-punk. htm . Acesso em 0I de fev. de 2019.

RUSSO, R. Faroeste Caboclo. Disponível em: https://www.vagalume.com.br/legiao-urbana/faroeste-cabloco.html . Acesso em 10 jan.2019.

SOARES, A. Gêneros Literários. 7.ed. São Paulo: Editora Ática, 2007.

VAGALUME. Músicas e discografia. Disponível em: https://www.vagalume.com.br/legiao-urbana/biografia/ . Acesso: 4 de fev.2019.

VAGALUME. Biografia da banda Legião Urbana. Disponível em: https://www.vagalume.com.br/legiao-urbana/biografial . Acesso: 02 de fev.2019.

VIEIRA, A. G. Do Conceito de Estrutura Narrativa à sua Crítica. In Psicologia: Reflexão e Crítica, 200I, I4(3), pp. 589-597. 